\title{
Effect of salt stress on the biochemical characteristics of selected wheat varieties
}

Sajjad $\mathrm{Ali}^{1}{ }^{*}$, Usman Ali ${ }^{1}$, Wisal Muhammad Khan ${ }^{2}$, Kashif Ali ${ }^{2}$, Muhammad Saleem Khan ${ }^{2}$ and Muhammad Shuaib ${ }^{3}$

1. Department of Botany, Bacha Khan University Charsadda, KP-Pakistan

2. Department of Botany, Islamia College Peshawar, KP-Pakistan

3. School of Ecology \& Environmental Science, Yunnan University, No.2 North Cuihu Road, Kunming, Yunnan, 650091, P.R-China

*Corresponding author's email: Sajjad_ali00@yahoo.com

Citation

Sajjad Ali, Usman Ali, Wisal Muhammad Khan, Kashif Ali, Muhammad Saleem Khan and Muhammad Shuaib. Effect of salt stress on the biochemical characteristics of selected wheat varieties. Pure and Applied Biology. Vol. 6, Issue 2, pp691-700. http://dx.doi.org/10.19045/bspab.2017.60073

\begin{tabular}{llll}
\hline \hline Received: 07/03/2017 & Revised: 18/05/2017 & Accepted: 28/05/2017 & Online First: 02/06/2017 \\
\hline
\end{tabular}

\section{Abstract}

Salt stress is one of the vital stresses consequential in decrease the yield and component of various crops including wheat (Triticum aestivum L.). Current practical was conducted to determine best variety of wheat (T. aestivum L.) for Charsadda under saline condition. The consequence caused by salt stress on the biochemical constituent (moisture, ash, crude fiber, crude fat, carbohydrates and protein) of five different varieties of wheat seeds grown under high artificial $\mathrm{NaCl}$ stress. During time period of sowing-harvesting different doses of $\mathrm{NaCl}$ were given to the plant. Result of approximate analysis showed reduction in moisture, ash, crude fiber and fat contents with increase in $\mathrm{NaCl}$ stress, while protein and carbohydrates contents increased with increase in salinity. On the base of percentage difference between control and 58g (higher concentration) Sahar and Siran varieties were less effected by $\mathrm{NaCl}$ stress in 4 out of 6 constituent even at $58 \mathrm{~g}$ (higher concentration) as compare to the Ta-Habib, galaxy 2013 and Janbaz.

Keywords: Salinity; Wheat; Proximate

Introduction

\section{Area back ground}

Study area is located in the west of the Khyber Pakhtunkhwa and is bounded by Malakand district on the north. Mardan district on the east, Nowshera and Peshawar district towards the south while Mohmand Agency of the Federally Administrated Tribal Areas on the West. The district lies between 34-03 and 34-38 North latitude and 71-28 and 71-53 east longitudes.

Charsadda features a semiarid climate, with very hot summer and cooled winter. Winter in Charsadda starts in a mid-November and ends in the late March, while summer months are May to September. The mean maximum summer temperature surpasses 40C (104F). The mean minimum temperature during winter is 4 degree centigrade minimum while maximum is 18.35 degree centigrade [1].

According to Censuses 1998 total population of Charsadda was recorded 1.626 million $(1,626,000)$, with area $996 \mathrm{~km}^{2}(385$ square miles) and density is $1026 / \mathrm{km}^{2}$ (2660/seq. mile). According to Geographic 
centre Charsadda, the district is 282 meter above from sea level in elevation.

Wheat crop in district charsadda

Saline stress alter the complete metabolism, physiological and enzymatic process, even it change the complete flexibility of a plant body [2, 3]. The strength of positive interactions increases with increasing stress except at the most extreme levels. In contrast, the strength of negative interactions is either unrelated to stress and remains consistently high, or alternatively, decreases with increasing stress [4]. Salt stress tolerance in plants is a complex phenomenon that may involve developmental process. Wheat (Triticum aestivum L.) is locally known as 'Ghundum'. It is grown world wise as Rabi (temperate) and is the leading word food crop so called 'king of cereals'. It is the major commodity in world food trade as it exceeds all cereals both in area and production. Due to its wide spread dissemination as food aid to developing countries wheat is considered as basic food stuff [5].

\section{Materials and methods}

An area of 320 square feet was selected within the university. 25 plots of area 2 square feet were made in the selected area. All the plots were 2 feet apart from each other from all the four sides. The partition between the plots was 2 feet width and 1 feet height wise. The area was well protected from the rain and fog with the help of plastic canopy during rain and fog events. Molar solution of $\mathrm{NaCl}$ was made for stock , 58.44 grams per 1 litre of water, 8 time water was given to the field, for each time 136 litres of molar of solute per litre of solution) stock solution was made which consume $7.947 \mathrm{~kg}$ of, $\mathrm{NaCl}$ from stock then further $0.7,0.8,0.9$ and 1 respectively concentration was made for treatments $T_{1}$, $\mathrm{T}_{2}, \mathrm{~T}_{3}$ and $\mathrm{T}_{4}$ respectively, by using simple formula.
$\mathrm{M}_{1} \mathrm{~V}_{1}=\mathrm{M}_{2} \mathrm{~V}_{2}$

$\mathrm{V}_{1}=$ volume required from stock.

$\mathrm{M}_{2}=$ required concentration .

$\mathrm{V}_{2}=$ total concentration of required solution.

$\mathrm{M}_{1}=$ Molarity of solute.

For $\mathrm{V}_{1}=\mathrm{M} 2 * \mathrm{~V}_{2} / \mathrm{M}_{1}$

$\mathrm{V}_{1}=0.7 * 10$ Litre $/ 1$

$\mathrm{V}_{1}=7$ Litre

$\mathrm{T}_{1}$ (0.7) concentration solution $=7$ Litre (stock) + 3 Litre (water) (contain $409 \mathrm{~g}$ $\mathrm{NaCl}$ )

Same formula for $T_{1}, T_{2}, T_{3}$ and $T_{4}$ respectively given below:

$\mathrm{T}_{2}(0.8)$ concentration solution $=8$ Litre (stock) + 2 Litre (water) (contain $468 \mathrm{~g}$ $\mathrm{NaCl})$

$\mathrm{T}_{3}$ (0.9) concentration solution $=9$ Litre (stock) + 1 Litre (water) (contain $526 \mathrm{~g}$ $\mathrm{NaCl})$

$\mathrm{T}_{4}$ (1) concentration solution $=10$ Litre (stock) only (contain $584 \mathrm{~g} \mathrm{NaCl}$ )

For each time 10 litre solution of salt was given to each plot.

Salt in grams per litre for $\mathrm{T}_{1}$ (41g/litre), $\mathrm{T}_{2}$ (47g/litre), $\mathrm{T}_{3}$ (53g/litre) and $\mathrm{T}_{4}$ (58g/litre).

Seeds were sown on 17 September, 2015 with first salt treatment, after that further salt treatment were given with the gap of 6 , $12,20,20,20,20$ and 8 days respectively. After two months wheat was harvested in the month of May, and then the seeds were collected manually and kept in plastic bags.

Seeds were grinded fine for approximate analysis. The approximate analysis was performed in the Chemistry Lab under the supervision of laboratory superintendent.

\section{Approximate analysis \\ For moisture content}

\section{Equipment's}

Oven, petri dish, $2 \mathrm{~g}$ sample was taken.

\section{Procedure}

Weight of the petri dish $\left(\mathrm{W}_{1}\right)$ and sample was taken before putting it into the oven. Place the petri dishes, partially covered in the oven for 4 hours to 6 hours at $105^{\circ} \mathrm{C}$. 
After 4 hours off the oven and let it to cool, after some time weighted $\mathrm{W}_{2}$ again.

Applying the formula

$$
\text { Moisture content }=\frac{\mathrm{W}_{1}-\mathrm{W}_{2}}{\text { Sample weight }} * 100
$$

For ash content

\section{Equipment's}

Furnace Dish, Crucible and furnace.

\section{Procedure}

Weight the empty crucible $\mathrm{W}_{1}$ and put $2 \mathrm{~g}$ sample in crucible, then put it in the furnace for 2 hours at $550^{\circ} \mathrm{C}$ highest temperature. After 2 hours off the furnace and let it cools. Then weight it $\mathrm{W}_{2}$ Weight of crucible + Ash in it.

$$
\begin{aligned}
& \text { Applying the formula } \\
& \text { Ash content }=\frac{\mathrm{W}_{2}-\underline{W}_{1}}{\text { Sample weight }} * 100
\end{aligned}
$$

\section{For crude fiber contents}

\section{Equipment's}

Beakers, Wash bath, $\mathrm{NaOH}, \mathrm{HCl}$, and titron filter, distilled water.

\section{Procedure}

Take 2 gram sample put it in the beaker. Put 2 percent $\mathrm{NaOH}$ solution of $200 \mathrm{ml}$ in the beaker. Place the beaker on wash bath for 4 hours. Filter the mass after the 4 hours, take the filtrate in a beaker and put $200 \mathrm{ml}(2 \%$ $\mathrm{HCl}$ solution) in the beaker and place it again at the wash bath for 4 hours. After that take the filtrate and put it in the crucible, and dry its moisture. For drying the moisture place the crucible again in the oven for 4 hours for $105^{\circ} \mathrm{C}$. The moisture will be evaporated $\mathrm{W}_{1}$ weight the dish, and then put the crucible in the furnace for 4 hours at $550^{\circ} \mathrm{C}$ after that again weight $\mathrm{W}_{2}$ the crucible.

\section{Applying the formula}

$\%$ of Crude fiber $=\frac{\mathrm{W}_{1}-\mathrm{W}_{2}}{\text { Sample weight }} * 100$

For fat contents

Equipment's

Soxhlet's apparatus. , Petroleum ether.

\section{Proceedure}

Take 1g sample fold it in the filter paper and then plant it into the inner coat of the timbal than fit the timbal in the Soxhlet's apparatus. Empty weight the beaker $\mathrm{W}_{1}$. Then after that pore $50 \mathrm{ml}-60 \mathrm{ml}$ petroleum spirit or ether in the beaker of the Sothic's apparatus, fit it at the timbal holder and air tight it, then switch on the apparatus, and fix it at the $6^{\text {th }}$ level. When the petroleum ether completely evaporates, recover the beaker and weight it again $\mathrm{W}_{2}$.

Applying the formula

$\%$ of Fat content $=\frac{\mathrm{W}_{2}-\underline{\mathrm{W}}_{1}}{\text { Sample weight }} * 100$

For protein contents

Material required

$1 \mathrm{~g}$ sample, $\mathrm{K}_{2} \mathrm{SO}_{4}, \mathrm{CuSO}_{4}, \mathrm{H}_{2} \mathrm{SO}_{4}$.

Proceedure

Digestion

Take the digestion flask put $1 \mathrm{~g}$ sample, $7 \mathrm{~g}$ $\mathrm{K}_{2} \mathrm{So}_{4}, 1 \mathrm{~g} \mathrm{CuSo}$. $10 \mathrm{ml}-15 \mathrm{ml} \mathrm{H}_{2} \mathrm{So}_{4}$ in the digestion flask, heat the flask up to greenish color, cold it then make the volume up to $100 \mathrm{ml}$ by putting distilled water in the flask. Pour the sample in a plastic bottle for distillation.

\section{Distillation}

\section{Equipment}

Jandal apparatus. Solution for one sample, 20ml Boric acid (4\%), 2-3 drops indicator (methyl red), $10 \mathrm{ml} \mathrm{NaOH} \mathrm{(40 \% ),} \mathrm{and} 10 \mathrm{ml}$ sample "digested sample".

\section{Titration}

Fill burret with $\mathrm{HCl} 0.1 \% \quad(4.41 \mathrm{ml}$ per $500 \mathrm{ml})$. Note the initial and final reading in titration.

Formula

Protein $\%=\frac{(\mathrm{S}-\mathrm{B}) * \mathrm{~N} * 0.014 * \mathrm{D}}{\text { weight of sample } * \text { volume }} * 100$ after that multiply the answer with nitrogen factor of wheat (6.25).

Where

$\mathrm{S}=$ sample reading

$\mathrm{B}=$ blank reading

$\mathrm{N}=$ normality of acid $(0.1)$

$0.014=$ milli equivalent weight of nitrogen

$\mathrm{D}=$ dilution factor $(100 \mathrm{ml})$ 
Weight of sample $=1 \mathrm{gm}$

Volume $=10 \mathrm{ml}$.

\section{For carbohydrate contents}

Formula is used carbohydrates $=100$ percentage value of (Moisture, ash, Crude fiber, fat and protein).

\section{Results}

The percent germination of wheat revealed that maximum percent germination was found in Sahar Variety followed by Punjab
2010 variety (Table 1) Approximate analysis of wheat seeds was conducted to test the effect of salt stress on the biochemical composition of selected varieties (galaxy 2013, Ta-Habib, Sahar, Janbaz ,Siran) of the Triticum aestivum L. different concentration of salts were applied as mentioned in the material and method chapter and the data were recorded.

Table 1. Percentage of Germination of different varieties.

\begin{tabular}{|l|c|}
\hline Variety & Variety per area \\
\hline Sahar & $30 \%$ \\
\hline Galaxy & $8 \%$ \\
\hline Janbaz & $2 \%$ \\
\hline Siran & $1 \%$ \\
\hline Ta- Habib & $1 \%$ \\
\hline Faisalabad & $5 \%$ \\
\hline Punjab 2010 & $15 \%$ \\
\hline Pirsabaak & $2 \%$ \\
\hline Wheat Total & $50 \%$ \\
\hline
\end{tabular}

\section{Effects of salt stress on moisture contents} of selected varieties of T. aestivum $L$.

The moisture content data were recorded which showed the dependent activity. The moisture contents were decreased with the increase in the salts concentration (Table. 2). Max reduced value showed by the $58 \mathrm{~g}$ higher concentration i.e. $7 \%$ while less i.e. $11 \%$ was showed by the $41 \mathrm{~g}$ lower concentration in the galaxy 2013 while control showed $12.5 \%$ moisture content. Similarly in case of Ta-Habib variety the lower concentration $41 \mathrm{~g}$ showed $7.5 \%$ moisture content, while maximum decreased moisture content showed by the $58 \mathrm{~g}$ higher concentration i.e. 5.9\%, (Table. 2) control was at $9.1 \%$. In case of Sahar variety the lower concentration 41g showed $9.15 \%$ moisture content while maximum reduction showed by the $58 \mathrm{~g}$ higher concentration i.e. $8.15 \%$, while control showed $10.95 \%$ moisture content. In case of Siran variety the lower concentration 41g showed 9\% moisture content while maximum reduction showed by the $58 \mathrm{~g}$ higher concentration i.e. $7.3 \%$, while control showed $9.2 \%$ moisture content. In case of Janbaz variety the lower concentration $41 \mathrm{~g}$ showed $8.5 \%$ moisture content while maximum reduction showed by the $58 \mathrm{~g}$ higher concentration i.e. $7 \%$, while control showed $10 \%$ moisture content (Table 2).

Effects of salt stress on ash contents of selected varieties of $T$. aestivum $\mathrm{L}$.

The ash content data were recorded which showed the dependent activity. The ash contents were decreased with the increase in the salts concentration. Max reduced value showed by the $58 \mathrm{~g}$ higher concentration i.e. $6.2 \%$ while less $8.5 \%$ was showed by the $41 \mathrm{~g}$ lower concentration in the galaxy 2013 while control showed $8.7 \%$ ash content. Similarly in case of Ta-Habib variety the lower concentration $41 \mathrm{~g}$ showed $8.5 \%$ ash content, while maximum decreased ash content showed by the $58 \mathrm{~g}$ higher concentration i.e. $6.75 \%$, control was at $10.5 \%$ (Table. 2). In case of Sahar variety 
the lower concentration $41 \mathrm{~g}$ showed $9 \%$ ash content while maximum reduced value showed by the $58 \mathrm{~g}$ higher concentration i.e. $8 \%$, while control showed $10.35 \%$ ash content. In case of Siran variety the lower concentration $41 \mathrm{~g}$ showed $8.7 \%$ ash content while maximum reduced value showed by the $58 \mathrm{~g}$ higher concentration i.e. $7.15 \%$, while control showed $9 \%$ ash content. In case of Janbaz variety the lower concentration $41 \mathrm{~g}$ showed $8.5 \%$ ash content while maximum reduction showed by the $58 \mathrm{~g}$ higher concentration i.e. $6 \%$, while control showed $10.5 \%$ ash content (Table 2). Effects of salt stress on crude fiber contents of selected varieties of $T$. aestivum $\mathrm{L}$.

The crude fiber content data were recorded which showed the dependent activity. The crude fiber contents were decreased with the increase in the salts concentration. Max reduced value showed by the $58 \mathrm{~g}$ higher concentration i.e. $5.15 \%$ while less $6.25 \%$ was showed by the $41 \mathrm{~g}$ lower concentration, while control showed $7.55 \%$ crude fiber content in the galaxy 2013 Similarly in case of Ta-Habib variety the lower concentration $41 \mathrm{~g}$ showed $6.8 \%$ crude fiber content, while maximum decreased crude fiber content showed by the $58 \mathrm{~g}$ higher concentration i.e. $5.9 \%$, control was at $7.87 \%$. In case of Sahar variety the lower concentration $41 \mathrm{~g}$ showed $6.7 \%$ crude fiber content while maximum reduced value showed by the $58 \mathrm{~g}$ higher concentration i.e. $6.1 \%$, while control showed $7.85 \%$ crude fiber content. In case of Siran variety the lower concentration $41 \mathrm{~g}$ showed $10.9 \%$ crude fiber content while maximum reduced value showed by the $58 \mathrm{~g}$ higher concentration i.e. $10 \%$, while control showed $12.1 \%$ crude fiber content. In case of Janbaz variety the lower concentration $41 \mathrm{~g}$ showed $8 \%$ crude fiber content while maximum reduction showed by the $58 \mathrm{~g}$ higher concentration i.e. $6 \%$, while control showed $10 \%$ crude fiber content (Table. 2).
Effects of salt stress on fat contents of selected varieties of $T$. aestivum $\mathrm{L}$.

The fat content data were recorded which showed the dependent activity. The fat contents were decreased with the increase in the salts concentration. Max reduced value showed by the $58 \mathrm{~g}$ higher concentration i.e. $6 \%$ while less $9 \%$ was showed by the $41 \mathrm{~g}$ lower concentration in the galaxy 2013 while control showed $11 \%$ fat content. Similarly in case of Ta-Habib variety the lower concentration $41 \mathrm{~g}$ showed $7.7 \%$ fat content, while maximum decreased fat content showed by the $58 \mathrm{~g}$ higher concentration i.e. $5.9 \%$, control was at $9.2 \%$. In case of Sahar variety the lower concentration $41 \mathrm{~g}$ showed $9.5 \%$ fat content while maximum reduced value showed by the $58 \mathrm{~g}$ higher concentration i.e. $7.8 \%$, while control showed $9.9 \%$ fat content. In case of Siran variety the lower concentration $41 \mathrm{~g}$ showed $9.5 \%$ fat content while maximum reduced value showed by the $58 \mathrm{~g}$ higher concentration i.e. $6 \%$, while control showed $9.8 \%$ fat content. In case of Janbaz variety the lower concentration $41 \mathrm{~g}$ showed $8.1 \%$ fat content while maximum reduction showed by the $58 \mathrm{~g}$ higher concentration i.e. $6.8 \%$, while control showed $9.8 \%$ fat content (Table 2).

Effects of salt stress on protein contents of selected varieties of $T$. aestivum $\mathrm{L}$.

The protein content data were recorded which showed that protein contents were increased with the increase in the salts concentration. Max increased value showed by the $58 \mathrm{~g}$ higher concentration i.e. $12.3 \%$ while less $9.63 \%$ was showed by the $41 \mathrm{~g}$ lower concentration in the galaxy 2013 while control showed $7.88 \%$ protein content. Similarly in case of Ta-Habib variety the lower concentration $41 \mathrm{~g}$ showed $11.4 \%$ protein content, while maximum increased protein content showed by the $58 \mathrm{~g}$ higher concentration i.e. $14 \%$, control was at $8.75 \%$. In case of Sahar variety the lower 
concentration $41 \mathrm{~g}$ showed $7.88 \%$ protein content while maximum increased value showed by the $58 \mathrm{~g}$ higher concentration i.e. $10.5 \%$, while control showed $7 \%$ protein content (Table. 2). In case of Siran variety the lower concentration $41 \mathrm{~g}$ showed $7.88 \%$ protein content while maximum increased value showed by the $58 \mathrm{~g}$ higher concentration i.e. $15.8 \%$, while control showed $7 \%$ protein content. In case of Janbaz variety the lower concentration $41 \mathrm{~g}$ showed $7.88 \%$ protein content while maximum increased value showed by the $58 \mathrm{~g}$ higher concentration i.e. $12.3 \%$, while control showed $7 \%$ protein content (Table 2).

Effects of salt stress on carbohydrate contents of selected varieties of $T$. aestivum $\mathrm{L}$.

The carbohydrate content data were recorded which showed that carbohydrate contents were increased with the increase in the salts concentration. Max increased value showed by the $58 \mathrm{~g}$ higher concentration i.e. $63 \%$ while less $56 \%$ was showed by the $41 \mathrm{~g}$ lower concentration in the galaxy 2013 while control showed $52 \%$ carbohydrate content. Similarly in case of Ta-Habib variety the lower concentration $41 \mathrm{~g}$ showed $55 \%$ carbohydrate content, while maximum increased carbohydrate content showed by the $58 \mathrm{~g}$ higher concentration i.e. $62 \%$, control was at $55 \%$. In case of Sahar variety the lower concentration $41 \mathrm{~g}$ showed $57.8 \%$ carbohydrate content while maximum increased value showed by the $58 \mathrm{~g}$ higher concentration i.e. $59.4 \%$, while control showed $54 \%$ carbohydrate content (Table 2). In case of Siran variety the lower concentration $41 \mathrm{~g}$ showed $54 \%$ carbohydrate content while maximum increased value showed by the $58 \mathrm{~g}$ higher concentration i.e. $63 \%$, while control showed $53 \%$ carbohydrate content. In case of Janbaz variety the lower concentration $41 \mathrm{~g}$ showed $58.5 \%$ carbohydrate content while maximum increased value showed by the $58 \mathrm{~g}$ higher concentration i.e. $61.9 \%$, while control showed $52.7 \%$ carbohydrate content (Table 2).

Table 2. Effect of NaCl concentrations on Moisture, Ash, Fiber, Fat, Protein and Carbohydrate of various wheat varieties

\begin{tabular}{|l|l|l|l|l|l|l|l|l|l|l|}
\hline Variety & \multicolumn{2}{|c|}{ Galaxy-2013 } & \multicolumn{2}{c|}{ Ta-Habib } & \multicolumn{2}{c|}{ Sahar } & \multicolumn{2}{c|}{ Siren } & \multicolumn{2}{c|}{ Janbaz } \\
\hline Parameter & Control & $\begin{array}{l}\text { Salt } \\
\text { treated }\end{array}$ & Control & $\begin{array}{l}\text { Salt } \\
\text { treated }\end{array}$ & Control & $\begin{array}{l}\text { Salt } \\
\text { treated }\end{array}$ & Control & $\begin{array}{l}\text { Salt } \\
\text { treated }\end{array}$ & Control & $\begin{array}{l}\text { Salt } \\
\text { treated }\end{array}$ \\
\hline Moisture & 12.5 & 9.4 & 9.1 & 6.6 & 10.95 & 8.6 & 9.2 & 8.1 & 10 & 7.7 \\
\hline Ash & 8.7 & 7.28 & 10.5 & 7.32 & 10.35 & 8.67 & 9 & 7.80 & 10.5 & 7.16 \\
\hline Fiber & 7.55 & 5.75 & 7.8 & 6.42 & 7.85 & 6.43 & 12.1 & 10.54 & 10 & 6.87 \\
\hline Fat & 11.0 & 7.50 & 9.2 & 6.78 & 9.9 & 8.57 & 9.8 & 8.77 & 9.8 & 7.38 \\
\hline Protein & 7.88 & 11.0 & 8.75 & 13.0 & 7.0 & 9.0 & 7.0 & 12.0 & 7.0 & 10.0 \\
\hline carbohydrate & 52 & 59.2 & 55 & 60.1 & 54 & 58.6 & 53 & 58.0 & 52.7 & 60.6 \\
\hline
\end{tabular}

\section{Discussion}

\section{Moisture contents}

In the present study increasing the dose of salt $(\mathrm{NaCl})$ stress reduced the moisture content by showing dependent activity. The moisture contents were decreased with increase in $\mathrm{NaCl}$ concentration. Maximum reduced value $7 \%$ showed by the $58 \mathrm{~g}$ higher concentration, while minimum reduced value $11 \%$ was showed by the $41 \mathrm{~g}$ lower concentration in the galaxy 2013, control showed $12.5 \%$ moisture content. The result is in covenant to of Ghoulam et al. [6] in this respect that they performed an experiment of water uptake and plant-water relationships under saline growth conditions on Tomato plant. The result showed that Growth and water uptake both decreases when tomato plants are irrigated with saline water. Similarly in case of Ta-Habib variety 
the lower concentration $41 \mathrm{~g}$ give minimum reduced value $7.5 \%$ moisture content, while maximum decreased moisture content showed by the $58 \mathrm{~g}$ higher concentration $5.9 \%$, control moisture content was $9.1 \%$. The result is in covenant to of [7] in this respect that they performed an experiment, Effects of salt stress on growth, inorganic ions and proline accumulation in relation to osmotic adjustment in five sugar beet cultivars. The result showed high $\mathrm{NaCl}$ concentrations caused a great reduction in growth parameters such as leaf area, and fresh and dry weight of leaves and roots, but the leaf number was less affected. These changes were associated with a decrease in the relative water In case of Sahar variety the lower concentration $41 \mathrm{~g}$ showed $9.15 \%$ moisture content while maximum reduced $8.15 \%$ moisture content showed by the $58 \mathrm{~g}$ higher concentration, and control showed $10.95 \%$ moisture content. The result is in agreement to those of Hernandez et al. [8] in this respect that they performed a $\mathrm{NaCl}$ stress experiment on pea plant. Their result showed both leaf water $\left(\psi_{1}\right)$ and osmotic potentials $\left(\psi_{\mathrm{s}}\right)$ decreased progressively with the severity of the stress. In case of Siran variety the lower concentration $41 \mathrm{~g}$ showed 9\% moisture content while maximum reduced $7.3 \%$ moisture content showed by the $58 \mathrm{~g}$ higher concentration, and control showed $9.2 \%$ moisture content. In case of Janbaz variety the lower concentration $41 \mathrm{~g}$ showed $8.5 \%$ moisture content while maximum reduced moisture content $7 \%$ showed by $58 \mathrm{~g}$ higher concentration and control showed $10 \%$ moisture content. The result is in agreement to the Khalil and Jan [9] in this respect that they performed an experiment of salinity against Atriplex griffithii var.stocksii. The result showed that water potential and osmotic potential of shoots became more negative with increasing salinity.

\section{Ash contents}

Ash contents decreased with increase in $\mathrm{NaCl}$ concentration. Extreme reduced $6.2 \%$ ash content was exposed by the $58 \mathrm{~g}$ higher concentration. Whereas fewer $8.5 \%$ was displayed by the $41 \mathrm{~g}$ lower concentration which was near to the control ash content $8.7 \%$ in the galaxy 2013. Similarly in case of Ta-Habib variety the lower concentration $41 \mathrm{~g}$ showed minimum effect $8.5 \%$ on the ash contents, but maximum decreased $6.75 \%$ ash content showed by the $58 \mathrm{~g}$ higher concentration, while control was at $10.5 \%$. In case of Sahar variety the lower concentration $41 \mathrm{~g}$ showed $9 \%$ ash content while maximum reduced value $8 \%$ exhibited by the $58 \mathrm{~g}$ higher concentration, although control showed $10.35 \%$ ash content. In case of Siran variety the lower concentration $41 \mathrm{~g}$ showed $8.7 \%$ ash content while maximum reduced value $7.15 \%$ showed by the $58 \mathrm{~g}$ higher concentration, whereas control showed $9 \%$ ash content. In case of Janbaz variety the lower concentration $41 \mathrm{~g}$ showed $8.5 \%$ ash content while maximum reduction $6 \%$ occurred by $58 \mathrm{~g}$ higher concentration . However control showed $10.5 \%$ ash content.

\section{Crude fibers contents}

$\mathrm{NaCl}$ high stress adversely affects crude fibers content; by increased $\mathrm{NaCl}$ concentration crude fibers content were decreased. Maximum reduction 5.15\% occurred at $58 \mathrm{~g}$ higher concentration, whereas less reduction in fiber content $6.25 \%$ was showed by the $41 \mathrm{~g}$ lower concentration, while control showed $7.55 \%$ crude fibers content in the galaxy 2013. Crude fibers content of the result is in agreement to those of [7] in this respect that they performed an experiment of salinity stress against wheat, the result shows that Salinity resulted in a significant reduction of the grain protein, fat and fiber contents. Similarly in case of Ta-Habib variety the lower concentration $41 \mathrm{~g}$ showed $6.8 \%$ crude fibers content, however maximum decreased 
$5.9 \%$ crude fibers content showed by $58 \mathrm{~g}$ higher concentration, but control was at $7.87 \%$. In case of Sahar variety the lower concentration $41 \mathrm{~g}$ showed $6.7 \%$ crude fibers content although maximum reduction $6.1 \%$ occurred at $58 \mathrm{~g}$ higher concentration, while control showed $7.85 \%$ crude fibers content. In case of Siran variety the lower concentration $41 \mathrm{~g}$ showed $10.9 \%$ crude fibers content while maximum reduced value $10 \%$ showed by the $58 \mathrm{~g}$ higher concentration, but control showed $12.1 \%$ crude fibers content. In case of Janbaz variety the lower concentration $41 \mathrm{~g}$ showed $8 \%$ crude fibers content while maximum reduction $6 \%$ crude fibers content showed by $58 \mathrm{~g}$ higher concentration, whereas control showed $10 \%$ crude fibers content. Only crude fibers result is in agreement to those of [8] who performed an experiment of salt stress on sunflower (sumsang-600) their result showed that increased salt stress caused reduction in crude fibers percentage.

\section{Fat contents}

Like moisture, ash and crude fibers content fat contents were also decreased with the increase in the $\mathrm{NaCl}$ concentration. Maximum reduced $6 \%$ value showed by the $58 \mathrm{~g}$ higher concentration, while minimum reduction $9 \%$ was showed by the $41 \mathrm{~g}$ lower concentration in the galaxy 2013, whereas control showed $11 \%$ fat content. Similarly in case of Ta-Habib variety the lower concentration $41 \mathrm{~g}$ showed $7.7 \%$ fat content, while maximum decreased fat content $5.9 \%$ showed by the $58 \mathrm{~g}$ higher concentration, control was at $9.2 \%$. In case of Sahar variety the lower concentration $41 \mathrm{~g}$ showed $9.5 \%$ fat content while maximum reduction $7.8 \%$ fat contents occurred at $58 \mathrm{~g}$ higher concentration, while control showed $9.9 \%$ fat content. In case of Siran variety the lower concentration $41 \mathrm{~g}$ showed $9.5 \%$ fat content while maximum reduced value $6 \%$ showed by the $58 \mathrm{~g}$ higher concentration, while control showed $9.8 \%$ fat content. In case of Janbaz variety the lower concentration $41 \mathrm{~g}$ showed $8.1 \%$ fat content while maximum reduced value $6.8 \%$ showed by the $58 \mathrm{~g}$ higher concentration, whereas control showed $9.8 \%$ fat content. Fat content of the result is in agreement to those of [9] in this respect that they performed an experiment of salinity stress against wheat, the result shows that Salinity resulted in a significant reduction of the grain protein, fat and fiber contents.

\section{Protein contents}

Protein contents were increased with the increase in the $\mathrm{NaCl}$ concentration. Maximum increased protein contents $12.3 \%$ showed by the $58 \mathrm{~g}$ higher concentration, while less $9.63 \%$ was showed by the $41 \mathrm{~g}$ lower concentration in the galaxy 2013, whereas control showed $7.88 \%$ protein content. Only protein content of the result is in contrast to those of Abbas et al. (2013) in this respect that they performed an experiment of salinity stress against wheat, the result shows that Salinity resulted in a significant reduction of the grain protein, fat and fiber contents. Similarly in case of TaHabib variety the lower concentration $41 \mathrm{~g}$ showed less $11.4 \%$ protein content, while maximum increased protein content showed by the $58 \mathrm{~g}$ higher concentration $14 \%$, but control was at $8.75 \%$. In case of Sahar variety the lower concentration $41 \mathrm{~g}$ showed $7.88 \%$ protein content while maximum increased value showed by the $58 \mathrm{~g}$ higher concentration i.e. $10.5 \%$, whereas control showed $7 \%$ protein content. In case of Siran variety the lower concentration $41 \mathrm{~g}$ showed $7.88 \%$ protein content while maximum increased value showed by the $58 \mathrm{~g}$ higher concentration i.e. $15.8 \%$, whereas control showed $7 \%$ Protein content. The result is in contrast to those of [10] in that respect that they performed an experiment of salinity stress against wheat. Their result showed that sugar, proline content increased with increasing salinity level where as protein 
content decreased in the physiologically active leaves of different treatments for all the varieties of wheat. In case of Janbaz variety the lower concentration $41 \mathrm{~g}$ showed $7.88 \%$ protein content while maximum increase in protein showed by the $58 \mathrm{~g}$ higher concentration i.e. $12.3 \%$, whereas control showed $7 \%$. The result is in agreement to those of [11] in that respect that they performed an experiment of salinity stress against Lycopersicon esculentum Mill. Their result showed that Increasing of salinity resulted in increasing of soluble proteins in stem and leaf.

\section{Carbohydrate contents}

Like protein carbohydrate content was increased with increase in the $\mathrm{NaCl}$ concentration. Carbohydrate contents were increased with the increase in the $\mathrm{NaCl}$ concentration. Maximum increased value showed by the $58 \mathrm{~g}$ higher concentration i.e. $63 \%$, while minimum carbohydrate contents $56 \%$ were showed by the $41 \mathrm{~g}$ lower concentration in the galaxy 2013, whereas control showed 52\% carbohydrate content. The result is in covenant to those of [12] in this respect that they performed an experiment for effects of salt stress on the ionic concentration of 4 Hordeum vulgare. The result showed that $\mathrm{NaCl}$ treatments increased the concentrations of soluble carbohydrate in the elongating tissues of the growing leaf. Similarly in case of Ta-Habib variety the lower concentration $41 \mathrm{~g}$ showed $55 \%$ carbohydrate content, whereas maximum increased carbohydrate content showed by the $58 \mathrm{~g}$ higher concentration i.e. $62 \%$, while control was at $55 \%$. In case of Sahar variety the lower concentration $41 \mathrm{~g}$ showed $57.8 \%$ carbohydrate content whereas maximum increased value showed by the $58 \mathrm{~g}$ higher concentration i.e. $59.4 \%$, though control showed 54\% Carbohydrate content. In case of Siran variety the lower concentration $\quad 41 \mathrm{~g}$ showed $54 \%$ carbohydrate content whereas maximum increased value showed by the $58 \mathrm{~g}$ higher concentration i.e. 63\%, while control showed $53 \%$ c content. In case of Janbaz variety the lower concentration $41 \mathrm{~g}$ showed $58.5 \%$ carbohydrate content whereas maximum increased showed by the $58 \mathrm{~g}$ higher concentration i.e. $61.9 \%$, while control showed $52.7 \%$ carbohydrate content. The result is in covenant to those of [13-15] in this respect that they performed an experiment for effects of salt stress on growth of Prosopis alba their result showed that total soluble carbohydrates increased with increase in salinity.

\section{Conclusion}

On the base of percentage difference between control and 58g higher concentration I came to conclude that Sahar and Siran Varieties are less effected by salt stress in 4 out of 6 (Biochemical) constituent even at $58 \mathrm{~g}$ (higher concentration ) they were less effected as compared to the TaHabib , galaxy 2013 and Janbaz.

\section{Authors' contributions}

Conceived and designed the experiments: $\mathrm{U}$ Ali \& S Ali, Performed the Experiments: U Ali \& K Ali, Analyzed the Data: MS Khan \& M Shuaib, Contributed reagents/ materials/ analysis tools: Muhammad W Khan \& S Ali, Wrote the paper: S Ali \& U Ali.

\section{References}

1. Abbas G, Saqib M, Rafique Q, Atiq ur Rahman M, Akhtar J, Anwar ul Haq M, \& Nasim M (2013). Effect of salinity on grain yield and grain quality of wheat (Triticum aestivum L.). Pak J Agri Sci 50(2): 185-189.

2. Ali I, Munir S, Sherwani SK, Rehman F U, Jamal Q., Abdullah K, Abbas MN \& Anees M (2013). Incidence of malaria in the urban and peri urban of District Charsadda Pakistan, fuuast J. Biol 3(2): 81-85.

3. Datta JK, Nag S, Banerjee A \& Mondal NK (2009). Impact of salt stress on five 
varieties of Wheat (Triticum aestivum L.) cultivars under laboratory condition. $J$ Appl Sci Envi Man 13(3): 93-97.

4. Ehsanpour AA, Amini F (2005). Soluble proteins, proline, carbohydrates and $\mathrm{Na}+\mathrm{K}+$ changes in two tomato (Lycopersicon esculentum Mill.) cultivars under in vitro salt stress. American Journal of Biochemistry and Biotechnology 1(4): 204-208.

5. Gaucherand S, Liancourt P \& Lavorel S (2006). Importance and intensity of competition along a fertility gradient and across species. Journal of Vegetation Science 17(4): 455-464.

6. Ghoulam C, Foursy A \& Fares K (2002). Effects of salt stress on growth, inorganic ions and proline accumulation in relation to osmotic adjustment in five sugar beet cultivars. Environmental and experimental Botany 47(1): 39-50.

7. Grime JP (1977). Evidence for the existence of three primary strategies in plants and its relevance to ecological and evolutionary theory. The American Naturalist 111(7): 1169-1194.

8. Hernandez JA, Campillo A, Jimenez A, Alarcon JJ \& Sevilla F (1999). Response of antioxidant systems and leaf water relations to $\mathrm{NaCl}$ stress in pea plants. New Phytologist 141(2): 241-251.

9. Khalil IA \& Jan A (2000). Cropping Technology. Millennium Ed. National Book Foundation Islamabad Pakistan pp.169-203.
10. Khan MA, Ungar IA \& Showalter AM (2000). Effects of salinity on growth, water relations and ion accumulation of the subtropical perennial halophyte, Atriplex griffithii var. stocksii. Annals of Botany 85(2): 225-232.

11. Khan WM, Khan MS, Karim S, Umar N \& Ali S (2016). Effect of salt stress on some morphological and biochemical characteristics of sunflower (Samsung600). Pure and Applied Biology 5(3): 653.

12. Meloni DA, Gulotta MR, Martínez CA \& Oliva MA (2004). The effects of salt stress on growth, nitrate reduction and proline and glycinebetaine accumulation in Prosopis alba. Brazilian Journal of Plant Physiology 16(1): 39-46.

13. Munns R, Greenway H, Delane R \& Gibbs J (1982). Ion Concentration and Carbohydrate Status of the Elongating Leaf Tissue 4Hordeum vulgare Growing at High External naclii. Cause of the growth reduction. Journal of Experimental Botany 33(4): 574-583.

14. Romero-Aranda R, Soria $\mathrm{T} \&$ Cuartero J (2001). Tomato plant-water uptake and plant-water relationships under saline growth conditions. Plant Science 160(2): 265-272.

15. Shao HB, Chu LY, Jaleel CA \& Zhao CX (2008). Water-deficit stress-induced anatomical changes in higher plants. Comptes Rendus Biologies 54(3): 215225. 